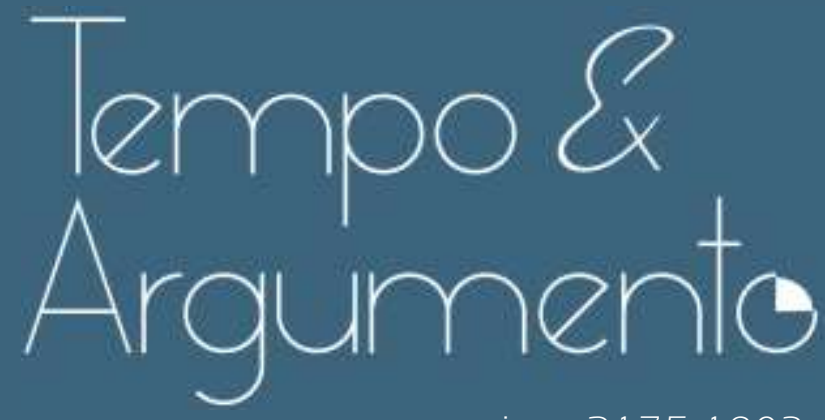

e-issn 2175-1803

"Memórias invisíveis": a produção de um documentário sobre o Abrigo Municipal de Alienados Oscar Schneider

- Mariana Zabot Pasqualotto

Doutora em Psicologia pela Universidade Federal de Santa Catarina (UFSC).

Florianópolis, SC - BRASIL

lattes.cnpq.br/9289120892067382

mariana.zabot@gmail.com

(D) orcid.org/0000-0003-2364-9075

- Andrea Vieira Zanella

Doutora em Psicologia da Educação pela Pontifícia Universidade Católica de São

Paulo (PUC/SP). Professora do Programa de Pós-Graduação em Psicologia da

Universidade Federal de Santa Catarina (UFSC).

Florianópolis, SC - BRASIL

lattes.cnpq.br/2409769589523805

avzanella@gmail.com

(D) orcid.org/0000-0001-8949-0605

Para citar este artigo:

PASOUALOTTO, Mariana Zabot; ZANELLA, Andrea V. "Memórias invisíveis":

a produção de um documentário sobre o Abrigo Municipal de Alienados

Oscar Schneider. Tempo e Argumento, Florianópolis, v. 13, n. 33, e0 114 ,

maio/ago. 2021

do) http://dx.doi.org/10.5965/2175180313332021 e0114

Recebido: 28/02/2021

Aprovado: 12/05/2021 
"Memórias invisíveis": a produção de um documentário sobre o Abrigo Municipal de Alienados Oscar Schneider

Mariana Zabot Pasqualotto, Andrea Vieira Zanella

\title{
"Memórias invisíveis": a produção de um documentário sobre o Abrigo Municipal de Alienados Oscar Schneider
}

\begin{abstract}
Resumo
Este artigo traz alguns sentidos produzidos na experiência de pesquisa e de produção de um documentário a respeito das memórias do território onde se fundou o Abrigo Municipal de Alienados Oscar Schneider (1923-1942), primeira instituição psiquiátrica de Joinville/SC. A edificação do Abrigo de Alienados foi realizada, na segunda década do século XX, aos fundos do território de um cemitério e distante do contato com o centro urbano. Após seu fechamento, sua estrutura física foi utilizada como Presídio Político (1942-1945) e, mais tarde, como moradia de famílias de policiais militares (1950-1970), até ser demolida, por volta de 1970, para fins de ampliação do cemitério. Neste artigo, narra-se a elaboração do roteiro e o processo de gravação do documentário "Memórias Invisíveis", constituído por entrevistas com testemunhas da existência do casarão e intervenções estéticoartísticas (performances e projeções de imagens) operadas no território atual onde existiu a edificação, a saber, o cemitério municipal. O artigo traz como resultados reflexões sobre a relação ética para com os vestígios das vidas que tiveram passagem na instituição psiquiátrica e aponta também para a importância política de estratégias de tensionamento de memórias invisibilizadas ligadas à história da loucura.
\end{abstract}

Palavras-chave: História da loucura; loucura; memória; Abrigo Municipal de Alienados Oscar Schneider.

\section{"Invisible memories": the Oscar Schneider Municipal Alienated People Shelter documentary production}

\begin{abstract}
This article discusses some senses produced in the research experience and production of a documentary about territory memories where was founded Oscar Schneider Municipal Alienated People Shelter (1923-1942), Joinville's first psychiatric institution. The shelter edification was realized, in second decade of twentieth century, at the bottom of a cemetery territory and far from urban center contact. After its closure, the physical structure was used as Politic Prison (1942-1945) and, later, as military police families habitation (1950-1970), until it was demolished, around 1970, in order to expand the cemetery. In this article, it is narrated the script elaboration and the "Invisible Memories" documentary recording process, constituted by interviews with witnesses of the mansion existence and aestheticartistic interventions (performances and images projections) operated in actual territory where existed the municipal cemetery edification. The article presents as results reflexions about ethical relation with lives traces that passed by the psychiatric institution and also points to political importance of invisibilized memories tensioning strategies connected to madness history.
\end{abstract}

Keywords: Madness History; madness; memory; Oscar Schneider Municipal Alienated People Shelter. 
"Memórias invisíveis": a produção de um documentário sobre o Abrigo Municipal de Alienados Oscar Schneider

Mariana Zabot Pasqualotto, Andrea Vieira Zanella

\section{Sobre o Abrigo M. de Alienados Oscar Schneider, caminhos e} fontes de pesquisa

Este artigo apresenta a experiência de pesquisa e de produção do documentário "Memórias Invisíveis", a respeito das memórias do território onde se fundou o Abrigo Municipal de Alienados Oscar Schneider (1923-1942), primeira instituição psiquiátrica de Joinville/SC, que recebeu as vidas consideradas e produzidas como alienadas nos meados do século XX.

A investigação a respeito do Abrigo Municipal de Alienados Oscar Schneider teve início em $2013^{2}$ com o objetivo de inventariar, em arquivos públicos, os vestígios documentais da existência da primeira instituição psiquiátrica de Joinville. A instituição se encontrava em um estado aparente de esquecimento na cidade. Eram raras as informações e testemunhas sobre esse lugar. Para o desenvolvimento da investigação, acessamos os documentos encontrados em arquivos públicos (Arquivo Histórico de Joinville e Arquivo Público do Estado), entre eles: notícias de jornais; o "Livro dos Alienados", registro de identificação dos pacientes; relatórios e correspondências que tratam sobre o número de pessoas internadas, diagnósticos, verbas destinadas à instituição e encaminhamentos; fotos da fachada do prédio; entre outros.

Sobre a fundação da instituição psiquiátrica, sabemos, a partir do Relatório da Superintendência de Joinville do ano de 1922, que o Abrigo Municipal de Alienados Oscar Schneider foi construído e oferecido ao município por Francisca Schneider "em cumprimento a última vontade de seu finado marido, o saudoso conterrâneo Snr. Oscar Antonio Schneider" (JOINVILLE, 1922, p. 126), ex-prefeito da cidade. Nesse documento menciona-se que o terreno para a construção da instituição foi doado pela administração pública e localizava-se aos fundos de um cemitério, fundado em 1913 num território afastado do centro urbano.

Anterior à criação do Abrigo de Alienados Oscar Schneider, tem-se conhecimento da existência de outro estabelecimento que recebeu a demanda

\footnotetext{
Na data da submissão deste artigo (fevereiro de 2021) o documentário ainda não havia sido lançado, mas sua produção encontrava-se concluída.

${ }^{2}$ Com o projeto "Inventário e Catálogo de Memórias do Abrigo Municipal de Alienados Oscar Schneider” (PASQUALOTTO; GOMES; SOARES; VIEIRA; BAPTISTA, 2013), patrocinado pela Fundação Cultural de Joinville através do Sistema Municipal de Desenvolvimento pela Cultura (SIMDEC), Edital de 2013, na modalidade de Patrimônio Imaterial.
} 
por confinamento das pessoas reconhecidas como loucas na cidade. Esse local é citado brevemente num outro trecho do mesmo Relatório da Superintendência de 1922 que trata dos esforços empreendidos sobre as dificuldades estruturais, a respeito da obtenção de água canalizada para o prédio, encontradas na construção do Abrigo de Alienados, da seguinte forma:

Não fosse isso [esforços empreendidos às dificuldades estruturais] teríamos de abandonar as nossas tentativas de transferir para esse novo estabelecimento os infelizes que ainda, devido unicamente a estas circunstâncias, permanecem no condenável pardieiro da rua Commandante Saturnino de Mendonça. (JOINVILLE, 1922, p. 126)

Assim se menciona o local em que se encontrava a primeira população dos considerados loucos que inaugurou o novo estabelecimento da cidade, seu Abrigo de Alienados, um “condenável pardieiro". Além disso, a ação filantrópica da viúva do ex-prefeito e as palavras escolhidas (presentes também em outros documentos da prefeitura e notícias de jornais) para descrever as pessoas consideradas alienadas, "infelizes”, confinadas em tais depósitos, coadunam com o pensamento do hospício como "um ícone benfazejo da humanidade civilizada e da benevolência cristã” (FONSECA, et al 2008, p. 36) presente no país, principalmente após o advento da República. Era um entre os "grandes palácios humanistas para reformar a humanidade" (ibid., p. 36). A justificativa para essas edificações voltava-se tanto para a proteção dos "normais" quanto para a dos "loucos".

No caso específico da loucura, além do medo para com a diferença mesma e seu contágio pestilento, moral e biológico, vemos, na justificativa das práticas de exceção, para além da garantia do bem geral, a busca do bem particular do insano. Tratase de protegê-lo de si, alienando-o dos direitos perante os demais e para si. Um sujeito jurídica, política e ontologicamente alienado. (FONSECA, 2008, p. 36)

A ideia dos hospícios como "Palácios para guardar doidos" é trabalhada por Wadi (2002) ao referir-se à forma como os hospícios vinham sendo criados no Brasil no decorrer do século XIX. Segundo a autora, os hospícios eram um dos pilares mais influentes da fundação e reconhecimento da psiquiatria como parte da ciência médica e dizem sobre uma nova relação que se estabeleceu com a 
"Memórias invisíveis": a produção de um documentário sobre o Abrigo Municipal de Alienados Oscar Schneider

Mariana Zabot Pasqualotto, Andrea Vieira Zanella

loucura, separando-a dos demais "desvios" sociais e criando a necessidade de um espaço de confinamento adequado aos "loucos".

O Abrigo Municipal de Alienados Oscar Schneider teve sua inauguração em meados do século XX e, portanto, um pouco atrasada em comparação ao momento em que surgiram hospícios em outras regiões do país. Mas, seguia em sua fundação ideais ligados à emergência das primeiras instituições psiquiátricas (FONTOURA, 2005).

Segundo Fontoura (2005), é através de medidas e discursos produzidos sobre a arquitetura e o espaço, e também sobre o comportamento e as relações de convívio de determinados grupos sociais que se dá o início à "modernizaçãourbanização" de Joinville, que se pautava em normas higiênicas da ciência moderna. Tratava-se de uma perspectiva eugênica/sanitarista para a modernização da cidade que passava por se preocupar com a saúde física, moral e intelectual da população.

Dentre os documentos relacionados à existência do Abrigo de Alienados, encontra-se um cartão-postal ${ }^{3}$ (Figura 1) com imagem da instituição psiquiátrica. Tal vestígio coaduna com o que diz Fontoura (2005) a respeito do contexto histórico da cidade na construção do hospício: demonstra que a sua fundação mobilizava certos olhares e interesses e que representava um acontecimento marcante na história do município.

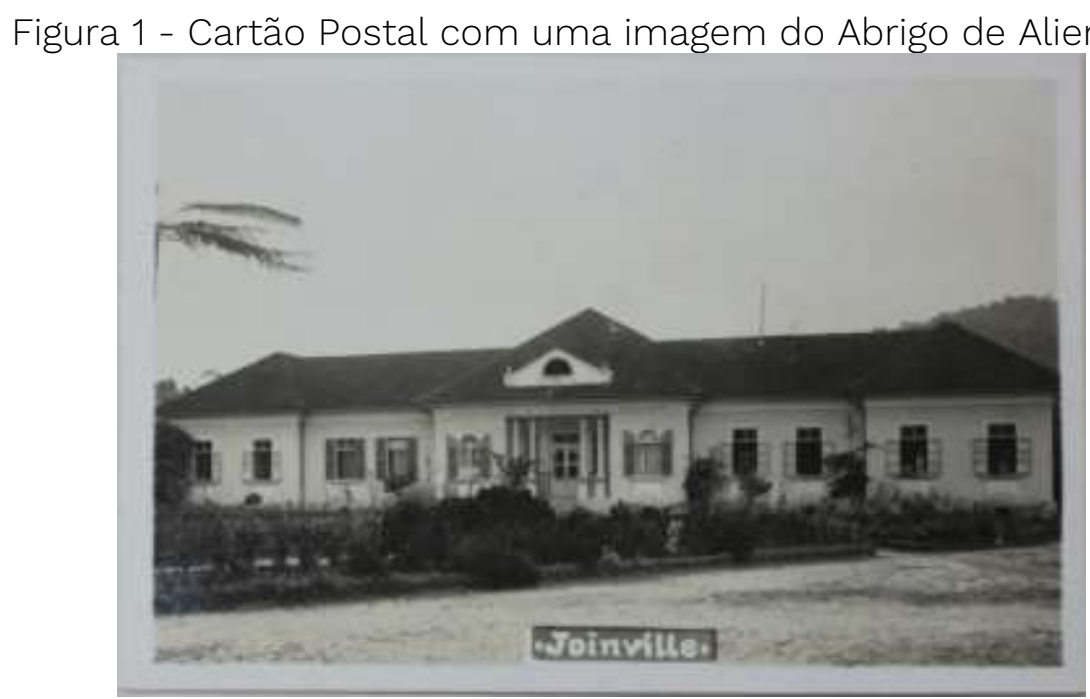

Fonte: Acervo do Arquivo Histórico de Joinville.

\footnotetext{
Assim como se encontra nos arquivos relacionados a muitos hospícios brasileiros (Wadi,
} 2002). 
"Memórias invisíveis": a produção de um documentário sobre o Abrigo Municipal de Alienados Oscar Schneider

Mariana Zabot Pasqualotto, Andrea Vieira Zanella

É interessante, ainda, mencionar que no documento sobre a inauguração do Abrigo de Alienados há a descrição do estabelecimento da seguinte forma:

Compõem-se o prédio de um corpo principal na frente, com alas lateraes e uma ala intermediária. A ala do centro está dividida em uma sala de jantar, cozinha, um quarto, banheiro e W.C. e é destinada a direção e funcionários. A da direita em um quarto para enfermeiro, banheiro e W.C. e sete cellas e um terraço. A da esquerda possue idênticos cômodos e é destinada a doentes do sexo feminino. No corpo principal estão localizados oito quartos para doentes não agitados e duas salas destinadas à Secretaria e à Diretoria. Na parte superior do edifício foram construídos três quartos com divisões de madeira, destinados ao pessoal empregado. (JOINVILLE, 1922, p. 126)

A partir dessa descrição, podemos observar que as características da sua estrutura condizem, em parte, com algumas sistematizações presentes em Tratados e Regulamentações ${ }^{4}$ construídos na França que previam especificidades a esse tipo de instituição: requeria-se que essas estruturas garantissem a salubridade da edificação; o afastamento de qualquer vizinhança para segurança e conforto de ambos os lados; uma separação mínima dos internos entre adultos e crianças, e entre gêneros; o isolamento dos convalescentes e furiosos; e, a vigilância sobre os pacientes. Além disso, os locais deveriam "agradar a vista”, e ter geometria retangular dispersiva, favorável à classificação dos pacientes (COSTA; FONSECA, 2008).

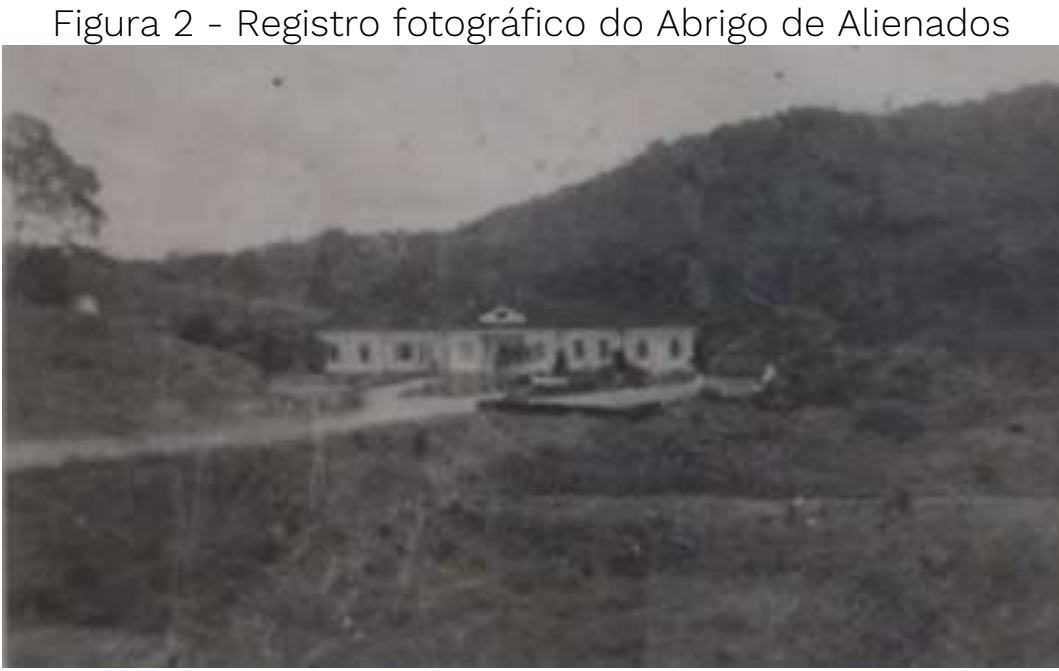

Fonte: Arquivo Histórico de Joinville

\footnotetext{
4 "Regulamentação de 1839 e o Tratado de Arquitetura" de Louis Cloquet em 1900 (COSTA; FONSECA, 2008).
} 
Dentre os registros fotográficos do Abrigo de Alienados, temos ainda na figura 2, a imagem que permite visualizar seu afastamento da vida urbana. Essa foi a destinação que se deu na demarcação dos territórios da urbe, uma oposição entre espaços sacralizados à habitação, aquilo que se vê como belo, ou digno de ser mostrado, por um lado, e por outro, o local de encarceramento e clausura dos infames. Essa imagem nos aproxima da realidade de uma cidade que criava seus próprios mortos-vivos; através delas, podemos ler as intenções políticas da época, os ideais de urbanização que correspondiam a certos modos de governar.

Fica evidente nesse contexto que a loucura é tratada como uma categoria social indesejante. Sobre isso, é importante entender, a partir de Foucault (2007), que nem sempre foi dada à loucura tal categorização, já que ela já foi vista, na Renascença, como sinônimo de saber esotérico e de sabedoria inacessível ao ser humano comum. É na modernidade, com sua inserção no contexto clínico, que ela passa a ser calada, sua criatividade é barrada e o pensamento rompido. Foucault (2007) sinaliza que quando a sociedade se firma centrada na racionalidade, alguns corpos perdem sua função no imaginário social, entre eles, os "loucos"; corpos que não se alinham à busca pela edificação de uma cidade perfeita. Às cidades modernas, regidas pelo capital, não interessavam os corpos vistos como improdutivos. A prática de internação do "louco", assim como dos "leprosos", aproxima-se da prática penitenciária a partir do século XIX respondendo ao objetivo de afastar certos sujeitos do meio social (FOUCAULT, 2007).

Após o fechamento do Abrigo Municipal de Alienados Oscar Schneider, as pessoas confinadas foram transferidas para uma recém-inaugurada instituição estadual, o Hospital Colônia Sant'Ana (1941) num contexto em que se inicia no Estado o processo de institucionalização da loucura numa perspectiva médicohospitalar (BORGES, 2013). A estrutura física da instituição passou a ser utilizada no mesmo ano do seu fechamento como Presídio Político (1942-1945) e, mais tarde, como moradia de famílias de policiais militares (1950-1970), até ser demolida, por volta de 1970, para fins de ampliação do cemitério. Diferente do Abrigo de Alienados Oscar Schneider, demolido cerca de 50 anos após sua 
"Memórias invisíveis": a produção de um documentário sobre o Abrigo Municipal de Alienados Oscar Schneider

Mariana Zabot Pasqualotto, Andrea Vieira Zanella

construção, cabe ressaltar que várias edificações de outros hospícios, segundo Wadi (2002), mantêm-se vivas nos cenários de muitas cidades brasileiras.

Como efeito do resultado da pesquisa iniciada em 2013 e que resultou em um livreto distribuído na cidade e, mais tarde, nas exposições e divulgações nas mídias sociais e no jornal local, 12 pessoas passaram a se configurar como testemunhas da existência desse território marcado pela construção do Abrigo de Alienados na cidade. Essas pessoas tiveram conhecimento sobre as exposições ou sobre a dissertação da pesquisadora através da internet e entraram em contato por meio da rede social facebook ou por e-mail.

As testemunhas vinculavam-se a alguns dos períodos da instituição ${ }^{5}$, direta ou indiretamente. Alguns/mas eram descendentes de pacientes ou de outras pessoas ligadas à história do território, seja do período da sua construção, ou do seu período como presídio político; algumas eram vizinhas da instituição ou haviam vivido no seu prédio quando este passou a ser uma moradia para famílias de policiais militares (1950-1970). Das testemunhas, com exceção de uma que não quis participar, 11 foram entrevistadas pela pesquisadora para a gravação do documentário "Memórias Invisíveis", pois atendiam ao critério de possuir alguma narrativa relevante à história da construção onde funcionou o Abrigo de Alienados.

As entrevistas, que seguiram a metodologia semiestruturada (Minayo, 1993) - ou seja, seguiram um roteiro de perguntas elaborado previamente, mas também aberto às imprevisibilidades dos encontros -, foram realizadas no formato de conversas nas casas dos/as entrevistados/as, ou em espaços outros, como o próprio cemitério, lugar onde, no passado, existiu o Abrigo de Alienados. As entrevistas foram gravadas por vídeo e áudio. Destaca-se que foram realizadas mediante assinatura do Termo de Consentimento Livre e Esclarecido (TCLE) e que a pesquisa foi aprovada pelo Conselho de ética.

O documentário "Memórias Invisíveis" foi constituído por entrevistas com as testemunhas e intervenções estético-artísticas: uma performance de atores/atrizes e projeções de imagens do antigo manicômio e de documentos

\footnotetext{
${ }^{5}$ Abrigo Municipal de Alienados Oscar Schneider (1923-1942); Presídio Político Oscar Schneider (1942/1945) e Moradia para famílias de policiais militares (190-1970).
} 
"Memórias invisíveis": a produção de um documentário sobre o Abrigo Municipal de Alienados Oscar Schneider

Mariana Zabot Pasqualotto, Andrea Vieira Zanella

que tratavam sobre sua construção e funcionamento no ambiente noturno do cemitério. A realização do documentário, a produção do seu roteiro, o encontro com as fontes orais, a construção dos elementos cênicos, foram fonte de análise deste artigo.

O projeto do documentário foi aprovado e patrocinado pelo Edital de Apoio à Cultura de Joinville (2018), sendo a produção gravada entre os anos de 2019 e 2021. A equipe de produção do documentário foi composta pela primeira autora deste artigo (roteiro), Ebner Gonçalves (direção), Guto Gonçalves (direção de fotografia, e edição), e vitor Suss (operador de câmera) ${ }^{6}$.

\section{Documentando "Memórias Invisíveis"}

O documentário "Memórias Invisíveis" apresenta fragmentos narrativos sobre os diferentes tempos do território - atual espaço do cemitério municipal de Joinville - onde foi fundado o Abrigo Municipal de Alienados Oscar Schneider (1923-1942). Esses fragmentos narrativos que compõem a constelação de sentidos do documentário compreendem: (1) trechos de entrevistas com testemunhas da presença física do prédio - da sua construção, dos diferentes acontecimentos a ele ligados e das histórias relacionadas às vidas que ali tiveram passagem; (2) diferentes intervenções estético-artísticas realizadas no espaço do cemitério $^{7}$, sendo elas: 2.1) uma performance realizada por um grupo de atores e atrizes representando as vidas invisibilizadas pela condição do isolamento no Abrigo de Alienados; 2.2) a instalação de um "varal" com as fichas de registros e fotos dos pacientes impressas em folhas transparentes; e 2.3) a projeção, no ambiente noturno do cemitério, de fotos do Abrigo de Alienados.

A produção da performance que compõe parte do documentário contou com a participação dos/as atores/atrizes Vinicius José, Clarice Steil Siewert, Eduardo Campos e Andreia Malena Rocha da Companhia de Teatro Dionisos, e Robson Benta, do Instituto de Pesquisa da Arte pelo Movimento - IMPAR, sob a

\footnotetext{
${ }^{6}$ Os três últimos trabalham no campo do audiovisual, na produção de filmes, documentários entre outros.

7 As intervenções não foram divulgadas ao público interessado, elas foram pensadas para compor o documentário exclusivamente.
} 
"Memórias invisíveis": a produção de um documentário sobre o Abrigo Municipal de Alienados Oscar Schneider

Mariana Zabot Pasqualotto, Andrea Vieira Zanella

direção do diretor de teatro Silvestre Ferreira (da Companhia de Teatro Dionisos). A realização da performance ocorreu no dia 19 de setembro de 2020, num sábado à tarde, no Cemitério Municipal de Joinville.

A ideia do cemitério como cenário para tais intervenções desenvolveu-se aos poucos, à medida que o roteiro ganhava forma, isto é, durante a produção, as saídas a campo, entrevistas, e na pré-elaboração da montagem das cenas. Havia algumas ideias iniciais que envolviam a participação dos atores em uma performance que seria realizada no centro da cidade, ou que convidaria as pessoas para conhecerem as memórias da loucura da cidade em um percurso que sairia do centro e chegaria até o cemitério, passando por dois outros locais que foram antigos espaços de isolamento da loucura: a rua do "antigo pardieiro", e a extinta Clínica Nossa Senhora da Saúde (1962 a 1986), cujo prédio ainda existe $^{8}$. Porém, em virtude de possíveis dificuldades de captação de imagens para o documentário que uma performance desse tipo colocaria em questão, optamos por desenvolver e registrar as intervenções artísticas unicamente no cemitério.

Além disso, a decisão de o cemitério ser palco único para a atuação dos atores também se deu porque, aos poucos, nos dávamos conta de que esse lugar se tornava o cenário principal a tensionar, ou simbolizar, a pluralidade de vozes; as luzes e as escuridões; as vidas, as mortes e o estado de espírito (FONSECA, 2018; PASQUALOTTO; ZANELLA; FONSECA, 2020) presentes na produção social de memórias de uma cidade.

Se a cidade é palco onde se experimentam - visivelmente ou não - as sobrevivências do passado, o cemitério, como lugar social, torna-se território simbólico a tensionar aquilo que desaparece, resta, sobrevive, metamorfoseia-se ou se conserva das inúmeras mortes de uma cidade. O cemitério tornou-se, assim, o cenário para a intervenção dos atores e de outras ações estéticas do documentário.

\footnotetext{
${ }^{8}$ sobre essa instituição, ver: SOUZA, Samira Sinara. A casa n.o 909 da Rua XV de Novembro: espaço praticado de memórias em Joinville. Dissertação (Mestrado em Patrimônio Cultural e Sociedade) - Programa de Pós-Graduação em Patrimônio Cultural e Sociedade, Universidade da Região de Joinville, Joinville, 2014.
} 
"Memórias invisíveis": a produção de um documentário sobre o Abrigo Municipal de Alienados Oscar Schneider

Mariana Zabot Pasqualotto, Andrea Vieira Zanella

\subsection{Sobre invisíveis}

"Sim, um Abrigo de Alienados de fato existiu nessa cidade": diante de reações de desconhecimento ${ }^{9}$ a respeito da existência da extinta instituição por parte de alguns serviços públicos municipais, ou de pessoas entrevistadas, foi preciso tentar validar, provar com registros documentais (fotos, relatórios da prefeitura da época), a veracidade da existência da instituição.

A partir da insistência em afirmar uma existência, que passava a ser creditada via documentos, operaram-se aberturas no campo: algumas pessoas passaram a escutar e se interessar pela história do ex-manicômio ou, a partir da fotografia ou de alguma outra informação a respeito do prédio do Abrigo de Alienados, passaram a se lembrar da sua paisagem na urbe ou de alguma história a ela ligada. Nesse sentido, produzir o documentário "Memórias invisíveis" nos aproximou também de uma prática ligada ao significado comumente dado ao verbo documentar (PRIBERAM, 2021) ${ }^{10}$ - que nos remete à reunião de registros palpáveis que forneçam validação sobre determinada versão de um acontecimento - pois, diante de uma narrativa pouco avivada que "descansa" em um cemitério, procuramos evidenciar "provas" da existência do Abrigo de Alienados e de pessoas que ali foram produzidas como infames.

Complementar a visão do documentário como reunião de provas, pensamos a partir de uma visão desconstruída de arquivo (DERRIDA, 2001), ou que faz ver sua perspectiva dialógica (BAKHTIN, 2013; ZANELLA, 2014), pois arquivos também são compostos por virtualidades, possibilidades perdidas, espectros, devires, dúvidas, cinzas, incertezas. Aquilo que se documenta, mais do que certezas e provas fatídicas sobre algo, são antes "pistas", "fragmentos" que apontam para uma versão possível, e não única, de olhar para determinado acontecimento, existência ou experiência passada.

\footnotetext{
9 Alguns acontecimentos da pesquisa de modo mais evidente ilustram esse movimento, como algumas visitas e contatos da pesquisadora com dois órgãos de salvaguarda de documentos relacionados a instituições e edifícios públicos do município. Ao pedir informações sobre vestígios documentais da antiga instituição psiquiátrica, obtive como reação, em ambas as situações, a incredibilidade a respeito da existência do Abrigo de Alienados.

10 De acordo com o dicionário on-line https://dicionario.priberam.org/documentar, temos como significados do verbo documentar a ação de "reunir documentos competentes a" ou "provar com documentos".
} 
Distanciando-se de uma tentativa única de construção de narrativa sobre a história do "território que abrigou alienados" em diferentes tempos, buscamos - na montagem, tratamento e produção das narrativas - visibilizar diferentes vozes, versões e tons, e nos implicamos no compromisso de visibilizar histórias de vidas facilmente esquecidas na tradição cultural da memória (ASSMANN, 2011), vidas que não foram consideradas dignas de luto (BUTLER, 2011).

Na experiência com a produção do documentário "Memórias Invisíveis", ganhou corpo a ideia de documentar o invisível. O tom da invisibilidade das memórias sobre o Abrigo de Alienados estava presente nos relatos dos/as entrevistados/as e passou a ser corporificado nas intervenções artísticas no cemitério. Dar uma face, um gesto, movimentos, encarnar revivescências e memórias quase apagadas, tensionar virtualmente a presença física que não mais existe, colocar em cena, no cenário do cemitério, as palavras escolhidas para construir o Abrigo de Alienados. Todas essas ações aproximavam de produzir por um instante e, ao mesmo tempo eternizar na gravação das cenas, visibilidades àquilo que desmoronou, mas que ainda perdura e permite estabelecer conexões de experiência. Partimos da suposição de que testemunhas não são apenas as pessoas, guardiãs das recordações, mas também todos nós que nos abrimos a uma experiência de outrora, que nos deixamos capturar pelas imagens vagalumes ${ }^{11}$ do passado (DIDI-HUBERMAN, 2011).

Como aponta Didi-Huberman (2011, p. 135), "uma experiência interior, por mais "subjetiva", por mais "obscura" que seja, pode aparecer como um lampejo para o outro, a partir do momento em que encontra a forma justa de sua construção, de sua narração, de sua transmissão." As imagens-vagalumes não são apenas testemunhos de um passado, mas também profecias, "previsões quanto à história política em devir" (DIDI-HUBERMAN, 2011, p. 138). Ou seja, elas

\footnotetext{
11 "Imagens- vagalumes" são, para Didi-Huberman (2011), imagens que vagam na escuridão de um passado pouco conhecido, produzindo pequenas luzes intermitentes, pequenos instantes em que se configuram experiências. Na sua obra "A sobrevivência dos vagalumes" (2011), o autor usa a metáfora dos vagalumes, proposta por Pasolini e, inspirando-se em Benjamin, diz que nada morre sem deixar algum rastro, tudo é ou pode ser significativo, algum sinal de si; assim, as "imagens - vaga-lumes" podem ser aquilo que, em pedaços constituídos por lampejos intermitentes, chega até nós.
} 
se inscrevem ao futuro e, como feixes de luz, apresentam-se aos olhares que não se deixam perder pelos clarões, mas sabem que é preciso também admirar a escuridão.

A partir das intervenções artístico-estéticas realizadas no cemitério, o documentário buscou imaginar invisíveis, possibilidades perdidas no passado. Apostando numa narrativa histórica tecida também pela arte, buscou-se possibilitar revivescências, correspondências entre o agora e o longínquo de outrora. E se o prédio ainda existisse? E se as primeiras pessoas que ali tiveram passagem, sendo internadas no Abrigo de Alienados, pudessem contar suas histórias, o que contariam?

$\mathrm{Na}$ aproximação com a arte para produzir conhecimento, passamos a apostar que as relações entre ciência e arte podem, talvez, ter efeitos outros na receptividade de leitores/as, expectadores/as.

Sobre arte, ciência e vida, Zanella aponta que

Interessa tanto na arte como na ciência provocar o/a expectador/a, mobiliza-lo/a, sensibiliza-lo/a aos encontros e afecções que exigem respostas, ações na esfera da vida com força para movê-la, intensificá-la, transformá-la. Interessa para além do mundo em que vivemos, reinventá-lo, o que exige a reinvenção das relações com os outros e com nós mesmas/os. (ZANELLA, 2017, p. 57)

Nesse sentido, a idealização do documentário e, especialmente, da performance e de outras intervenções estéticas que o compõem, surgiu como forma de produzir conhecimento, de provocar respostas críticas e sensíveis no/a expectador/a em relação à história do Abrigo de Alienados. O caminho estético - escolhido para narrar essa história a contrapelo (BENJAMIN, 2012) - nos coloca diante

[...] de uma poética que é feita para produzir um conhecimento distante dos racionalismos e funcionalismos. Conhecimento implicado à vida dos sujeitos, experimentada em meio a lutas discursivas que convulsionaram tanto o plano da política quanto o das ciências e técnicas e da cidade. (PASQUALOTTO; ZANELLA; FONSECA, 2020, p. 15) 
O caminho da produção artística surgiu, por fim, como uma aposta diante da nossa relação com as vidas sobre as quais restam pouquíssimas informações; as vidas quase sem história que nesse local tiveram passagem.

Imaginar seus gestos, seus passos e sentimentos na atuação dos atores; tensionar suas (in)visibilidades, seus apagamentos e sobrevivências nas fichas de registro impressas em transparências; visibilizar as palavras que um dia foram escolhidas para se referirem a essas vidas e à construção de um lugar para seu isolamento nas projeções de vídeo na escuridão do cemitério: foram esses os exercícios de virtualização histórica com os quais trabalhamos. Uma aposta de produção de aberturas para possíveis relações estéticas com um lugar apagado da paisagem urbana e borrado nas linhas escritas pela produção social da memória na cidade.

\subsection{Performando (in)visíveis}

O processo de criação da performance artística no cemitério envolveu algumas reuniões com os atores ao longo do processo de gravação do documentário até que, reunindo ideias que surgiram nesses momentos, e momentos outros a partir da gravação das entrevistas, escreveu-se uma espécie de roteiro para a performance, algo para direcionar o conceito do que seria produzido naquele dia. O "roteiro" foi discutido em uma reunião final com atores, quando se chegou o mais perto possível de um conceito para as intervenções: seriam atuações que representariam a memória dos corpos que foram apagados pela segregação e pelo esquecimento, inspiradas nas fichas de registros das pessoas internadas e nas suas fotos. Falamos também sobre a abertura para criação que aconteceria no dia, a partir de alguns exercícios propostos pelo diretor de teatro Silvestre Ferreira, ou algumas interferências propostas pela própria equipe do documentário. Ainda que se tivesse um roteiro de possíveis intervenções a serem realizadas, algumas ideias previstas no roteiro foram colocadas em prática, outras não, e a maioria nasceu da improvisação naquele momento.

Marcamos uma ambientação, uma espécie de ensaio com as câmeras, com checagem de figurinos e realização das experimentações primeiras, o que 
"Memórias invisíveis": a produção de um documentário sobre o Abrigo Municipal de Alienados Oscar Schneider

Mariana Zabot Pasqualotto, Andrea Vieira Zanella

ocorreu no dia 14 de setembro de 2020, uma segunda-feira, no Cemitério Municipal. Não foi realizada solicitação formal à administração do cemitério para a realização das intervenções. Durante os dias do ensaio e realização da performance, contamos com o apoio de alguns trabalhadores que nos informaram os horários apropriados para utilizarmos determinados espaços do cemitério, tendo em vista o respeito aos sepultamentos que estavam ocorrendo naquelas ocasiões.

No dia do ensaio, a equipe se reuniu nos arredores do cemitério e, primeiramente, os atores experimentaram alguns figurinos para a prova. Após escolhermos os figurinos tendo como base as fotografias do Livro de Alienados, dirigimo-nos para a área onde existiu o prédio da instituição. Os atores encenaram intervenções possíveis enquanto treinava-se com as câmeras a captação dos melhores ângulos.

Era uma segunda-feira à tarde e, trabalhadores e visitantes circulavam pelo cemitério. Em um determinado momento, o diretor da companhia de teatro explicou para uma família que realizava uma visita a um túmulo do que se tratava nossa presença ali, e o membro mais antigo da família disse se recordar do prédio. "É mesmo, agora você falando eu me lembrei. O prédio ficava bem aqui [diz e aponta], era um sanatório.” (D1, 2020. Informação verbal.). Em outro momento, um trabalhador se aproximou de dois atores, já sabendo do que se tratava aquela intervenção, e disse que morou no prédio com a sua família quando ali existiu a Moradia para as famílias do militares. "Eu nasci no cemitério, e nunca mais saí, trabalho até hoje aqui” (D2, 2020. Informação verbal.). Pediu-se que ele participasse do documentário, aproveitando a presença da câmera. Ele, porém, não quis participar e disse que quem sabia contar muitas histórias sobre o prédio era a sua mãe, já falecida.

Interessante pensar que diante da presença da equipe no dia de ensaio naquele território se produziram efeitos: o ensaio já se deu como uma intervenção no estado nublado das memórias sobre o Abrigo de Alienados. Diante de uma presença física e simbólica daquela memória, representada pela presença da câmera, de atores e de uma movimentação estrangeira àquele lugar, efervesceram narrativas e testemunhos, o que corrobora a ideia de Abreu (2012) 
"Memórias invisíveis": a produção de um documentário sobre o Abrigo Municipal de Alienados Oscar Schneider

Mariana Zabot Pasqualotto, Andrea Vieira Zanella

de que a memória não se preserva sozinha, mas necessita de agentes e de suportes para tal.

Figura 3 - Participação dos/as atores/atrizes no documentário

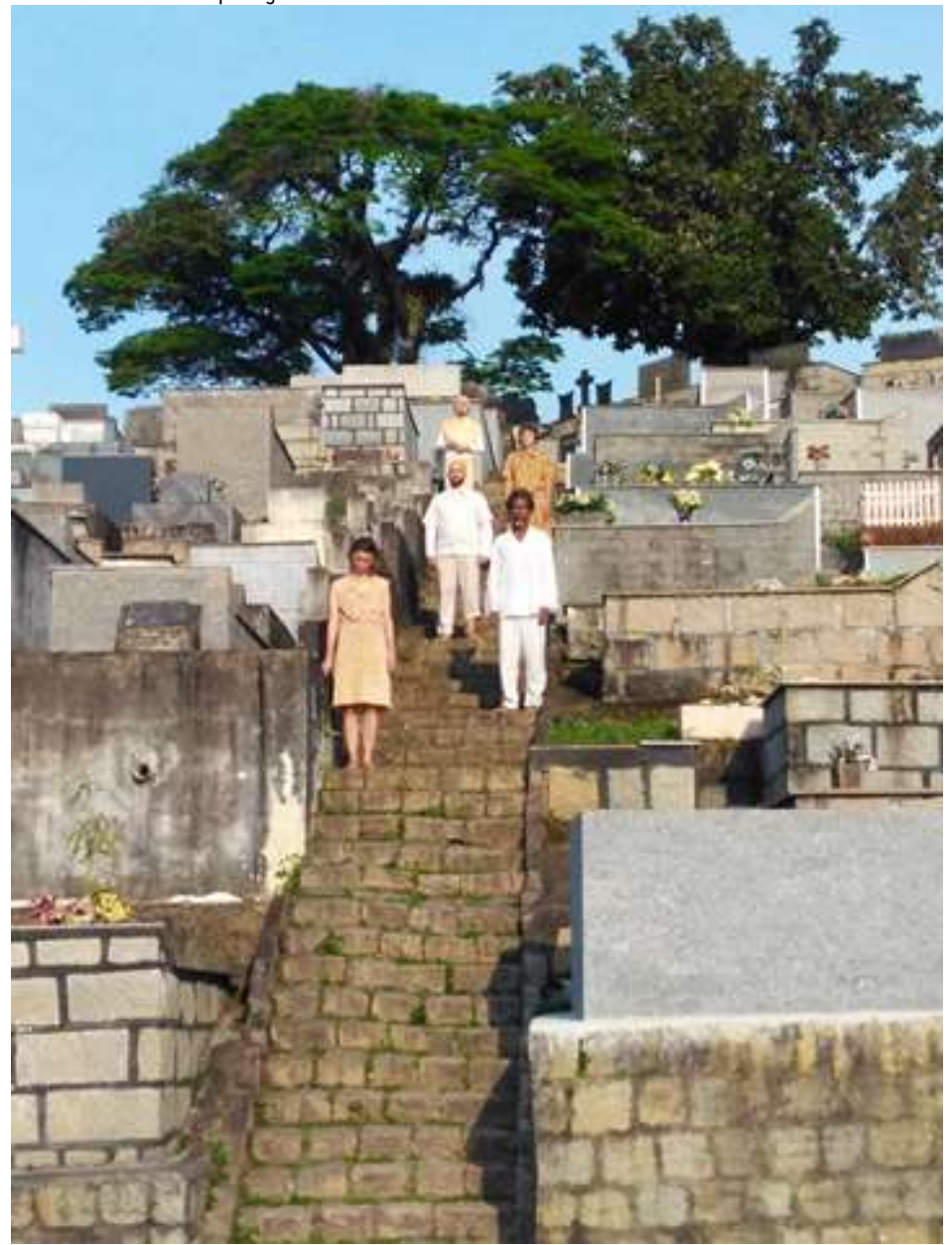

Fonte: Acervo da pesquisadora.

A gravação oficial para o documentário ocorreu dias depois do ensaio, no dia 19 de setembro de 2020, um sábado. Inicialmente, gravamos a cena dos atores descendo as escadarias do cemitério (figura 3). Uma das tomadas dessa cena foi um enquadramento nos passos dos atores. Essa ideia surgiu após uma conversa com o diretor de teatro, Silvestre Ferreira, sobre possíveis intervenções poéticas dos atores no cemitério. Retivemos essa ideia como uma das cenas possíveis dos atores, que depois foi pensada como a abertura da participação da performance no documentário.

Elaboramos a ideia de que explorar os corpos e os movimentos dos atores de forma misteriosa na paisagem do cemitério poderia se configurar como dispositivo para irmos costurando os fragmentos das entrevistas. Assim, no 
"Memórias invisíveis": a produção de um documentário sobre o Abrigo Municipal de Alienados Oscar Schneider

Mariana Zabot Pasqualotto, Andrea Vieira Zanella

documentário, poderíamos ir operando com as incertezas trazidas pelas testemunhas, pelo desconhecimento que se colheu na cidade ao longo da pesquisa de campo.

Sobre as incertezas trazidas pelas testemunhas, algumas versam sobre a origem da construção do prédio, como nos demonstram as entrevistas com as antigas crianças, filhas de policiais militares, que habitaram o casarão por algum período nos seus últimos 20 anos de existência física. As falas foram retiradas de um encontro produzido pela equipe do documentário realizado na casa de Marisa, uma desses habitantes, filha de um soldado, cuja família habitou a Moradia durante os anos 1950. Marisa procurou a pesquisadora para contar suas histórias e se dispôs a entrar em contato com seus antigos amigos, na época também crianças, que assim como ela habitaram aquele lugar. Cientes da proposta do documentário, Marisa conseguiu reunir mais quatro testemunhas desse período para um encontro em sua casa para a gravação para o documentário; são eles/elas: Marilu, Selma, Idenir e Roni².

No dia do encontro, chegamos (equipe de produção do documentário) mais cedo à casa da Marisa com a intenção de preparar as câmeras e registrar as cenas iniciais do encontro. Preparamos algumas fotos e notícias de jornais e colocamos sobre uma mesa onde ocorreria a reunião. Os demais participantes chegaram juntos e logo passaram a observar e trocar fotografias que serviram como dispositivo para inúmeras memórias. Nesse encontro, evocaram lembranças sobre a infância naquele lugar. Falaram sobre caçar na mata aos fundos do cemitério, sobre apresentações de teatro que eram feitas no antigo salão do prédio, sobre medo, sobre não ter medo, sobre "más energias" (sic), sobre "espíritos" (sic), sobre a existência de "ladrões de galinha" (sic) (MARISA, 2020. Informação verbal.) que eram presos aos fundos do prédio, em celas ainda existentes. Filmamos pouco mais de meia hora de conversa entre eles e a pesquisadora e, em um segundo momento, propusemos uma pausa para realizar perguntas mais diretas da pesquisadora a cada um deles.

\footnotetext{
12 Utiliza-se neste artigo o primeiro nome dos/as entrevistados/as que assinaram um Termo de Consentimento para tal.
} 
Destacamos um diálogo que ocorreu durante esse encontro entre Roni, Idenir, Selma e a pesquisadora sobre a origem do prédio e sobre a sua fachada em que podemos observar que os/as entrevistados/as não tinham conhecimento sobre o que estava escrito antes do nome "Oscar Schneider" nem sobre o funcionamento do Abrigo de Alienados:

- Quando a gente morou lá, nunca ouviu falar que era hospício, só cadeia. (RONI, 2019. Informação verbal.).

- Olha, até aqui no jornal eles colocaram. [Reportagem divulgando a exposição sobre o Abrigo de Alienados no Arquivo Histórico] (IDENIR, 2019. Informação verbal.).

- Não, mas não era hospício... (RONI, 2019. Informação verbal).

- Tinha algo escrito na faixada do prédio? (Pesquisadora)

- Só "Oscar Schneider"... Tinha um primeiro nome ali, mas não se sabe, tava esfumaçado. (RONI, 2019. Informação verbal.)

- Não dava pra ver se tava escrito "presídio" ou "Asilo"? (Pesquisadora)

- Não, tinha um nome e depois vinha Oscar Schneider... esse primeiro nome que tá uma incógnita, ninguém sabe o que é. [...] Tava esfumaçado, a fumaça tampou. (RONI, 2019. Informação verbal)

- Mas, hospício é de louco né? Vishhhh... Hospício é mais pesado ainda. (SELMA, 2019. Informação verbal). (Diálogo presente em cena do documentário "Memórias Invisíveis)

A partir desse diálogo entendemos que, desde a década de 1950, o desconhecimento sobre a existência da instituição psiquiátrica já se fazia presente na cidade, ou que houve algum silenciamento: talvez os pais das testemunhas que viveram durante a infância nesse lugar não tenham transmitido tais informações. Uma história não contada. Talvez, diante da condição precária da moradia, saber sobre sua origem como manicômio era "mais pesado ainda", como nos faz pensar Selma.

Através dessas dúvidas e silenciamentos, exploramos o tom de mistério que o cenário do cemitério - no desenvolvimento inicial da performance dos atores - e os primeiros relatos das testemunhas nos levam a experimentar. Esse primeiro eixo temático do documentário, a respeito do desconhecimento na cidade sobre a existência do Abrigo de Alienados, também se expressa na seguinte fala do entrevistado Dilney Cunha, historiador e atual diretor do Arquivo Histórico de Joinville, durante a realização da entrevista para o documentário: 
Eu mesmo tenho meus vinte e poucos anos como pesquisador, mas eu posso dizer que só recentemente, menos de dez anos, eu tomei contato com a existência dessa instituição. E não foi por conta dela, mas foi por conta do campo de internamento, campo de concentração dos presos políticos durante a Segunda Guerra Mundial. E aí eu fui descobrir que não foi construído para ser isso, foi construído para ser um hospital de alienados. (CUNHA, 2019. Informação verbal.)

A fala de Dilney Cunha vem de outro lugar de experiência, diz sobre sua relação como historiador que narra o desconhecimento relacionado às memórias desse território. Desconhecimento que, assim como os relatos das testemunhas que viveram na moradia, é maior em relação à origem do casarão como Abrigo de Alienados.

Até esse momento do documentário, percorremos um caminho mostrando a história desse lugar em sua intimidade com o cemitério, a incerteza e as diferentes intencionalidades acerca dos motivos que levaram à demolição da estrutura física do ex-Abrigo, e o desconhecimento de sua origem. Começamos pelos últimos suspiros da presença física do casarão e passamos, a partir desse momento, a embaralhar os "capítulos", como se colocássemos diferentes tempos a conversarem entre si. Afinal, entendemos esse espaço como cronotopo, como lugar de interação de diferentes tempos.

Lembranças como as de Marilu, ex-habitante da Moradia de militares, que conta: "A gente caçava na mata aos fundos do cemitério, brincava entre os túmulos, não tinha medo...” (MARILU, 2019); as falas de Marisa, também exhabitante da Moradia de militares, que por sua vez recorda: "Tinha também aquelas apresentações de teatro que a gente fazia, vocês lembram? A gente se apresentava no salão do prédio [...] parecia uma antiga recepção" (MARISA, 2019), e que em outro momento diz: "Eu voltaria a morar no prédio caso fosse reconstruído" (MARISA, 2019); ou também a fala de Selma que diz: "O dia mais feliz da vida da minha mãe foi quando ela conseguiu sair de lá com a gente" (SELMA, 2019; todas essas falas mostram os diferentes sentidos e relatos atribuídos à experiência de morar num antigo manicômio e presídio e sentimentos contraditórios das pessoas cujas histórias de vida se entretecem com a história daquele lugar. 
"Memórias invisíveis": a produção de um documentário sobre o Abrigo Municipal de Alienados Oscar Schneider

Mariana Zabot Pasqualotto, Andrea Vieira Zanella

\subsection{Histórias silenciadas}

Quando se adentra no documentário sobre a origem do casarão, ligada à inauguração de um Abrigo de Alienados, movimentos outros dos atores, a partir de gestos e encenações inseridas em uma linguagem narrativa crescente, vão "dando corpo", de modo mais evidente, às memórias ausentes das pessoas "alienadas". A narrativa do documentário procura, dessa forma, seguir um caminho que vai dos mistérios e ausências à corporificação ou encarnação de vivências.

Recordamos aqui como foi dirigida uma das cenas para trazer um pouco do que foi vivido na experimentação artística no cemitério. Enquanto uma das atrizes, Clarice Siewert, encenava sua personagem caminhando entre túmulos, com olhar vagante, o diretor passou a disparar algumas frases como forma de gatilho para a sua encenação. As frases foram se tecendo no contexto de uma suposta espera da paciente por uma visita de um familiar: "Clarice, eu tô aqui. Eu tô aqui fora, olha pra mim!", "Clarice, hoje eu não posso te visitar. Hoje eu não vou. Tô indo embora" (FERREIRA, 2020). Essas foram algumas frases que sensibilizaram a atriz e a equipe naquele momento. As frases usadas pelo diretor se aproximam dos sentimentos vivenciados na experiência da clausura, no afastamento dos entes queridos, na angústia do abandono, na impossibilidade das sociabilidades extramuros, como nos mostram os registros/relatos biográficos, estéticos e orais de pessoas que passaram pela experiência do confinamento manicomial ${ }^{13}$.

Esse relato é um exemplo dos bastidores, das nuances que não aparecem no resultado final do documentário, mas fazem parte do que foi vivido durante a tarde de revivescências artísticas no cemitério e dizem sobre a construção ética do olhar para essas vidas no processo de sua realização.

Sobre a construção ética que conduziu a experiência da construção artística a representar as memórias das vidas alienadas, podemos dizer que ela vem sendo maturada desde a pesquisa do mestrado (PASQUALOTTO, 2016).

\footnotetext{
${ }^{13}$ como se pode ver em: FONSECA, T. M. G.; BRITES, B. L. A exposição EU SOU VOCÊ e seus encontros alegres. In: FONSECA, T. M. G.; BRITES, B. L. (orgs.). Eu sou você. Porto Alegre, RS: UFRGS, 2012.
} 
Portanto, a pesquisa emprestou seu olhar crítico e sensível à produção artística, vendo no resultado da performance esse olhar se objetivar, fora da forma da produção acadêmica; ao mesmo tempo, a performance abre novamente a pesquisa a novos possíveis, a sentidos ainda não produzidos, a ressignificações, a novos olhares.

O documentário chega também a versar sobre as histórias e os silêncios que circulam nas famílias sobre as vidas de pessoas que passam pela experiência do confinamento manicomial. Durante a pesquisa de mestrado e doutorado, três descendentes de pacientes entraram em contato com a pesquisadora por possuírem alguma pista sobre a passagem de seus parentes no Abrigo de Alienados Oscar Schneider e terem interesse em pesquisar a história dessas vidas silenciadas nas famílias. As pistas, nos três casos, vinham de histórias que envolviam algum murmúrio que circulava discretamente entre a família sobre algum "traço de loucura" ligado aos seus antecedentes. Em todos os casos, os resquícios das existências dessas vidas eram mínimos. Estávamos diante de histórias silenciadas. A pesquisadora colocou-se à disposição para ajudar na pesquisa no Arquivo Histórico de Joinville sobre a passagem de seus descendentes no Abrigo de Alienados, mas, apenas um desses descendentes, Lucas Muenster, aprofundou a pesquisa e, mais tarde, participou do documentário "Memórias Invisíveis" compartilhando os rastros encontrados sobre a vida de sua trisavó, Hedwig Marta Becker.

No documentário, mostra-se a cena da entrevista com Lucas e o seu encontro no Arquivo Histórico de Joinville com os rastros da vida de sua trisavó em sua passagem pelo Abrigo de Alienados. A cena significou, de certa forma, o ato de "dar as devidas lápides" a uma história silenciada. Um pouco antes da gravação, a pesquisadora e o entrevistado fizeram uma conversa sobre como tinha se dado a busca pelos rastros de Hedwig até então. Reunimos alguns dados encontrados e rascunhamos uma conjectura de sua história de vida, que Lucas por último narrou no final da entrevista da gravação para o documentário. Assim Lucas descreveu a história da sua trisavó: 
Ela nasceu Edwig Martha Reiche, em Eisleben, na Alemanha, dia 6 de outubro de 1903. Ela era filha de Hugo Rodrich Arno Becker e Hedwig Berta Reiche Becker. A informação que nós temos é que eles, a Frau Becker [mãe de Hedwig] e o Hugo, junto com a Hedwig e os outros filhos, migraram para o Brasil em 1914. Chegaram pelo Porto de Santos e então eles se dirigiram pra Joinville. Nasceu um outro filho em Joinville, e depois eles se dirigiram para Florianópolis onde assentaram pouso. [...] Ao que se sabe, ela [Hedwig Martha] era doméstica, teve 5 filhos - os registros desses filhos são casos próprios porque cada um teve um destino. E ela desaparecia - essas informações a gente foi adquirindo depois da pesquisa - ela desaparecia nos anos 1930; ela simplesmente sumia. E aí nós fomos encontrar ela aqui né. [...] o nome dela aqui na ficha é Hedwig Manderbach, que é justamente o nome de casado dela. [...] a minha bisavó contava que a mãe dela tinha morrido quando ela tinha sete anos. Sete anos fechava em 1935. Ela aniversariava em maio e a mãe entra novamente [no Abrigo de Alienados Oscar Schneider] em 19 de janeiro de 1935. Então ela entra e nunca mais sai. Ela falece dia 20 de janeiro de 1937. [...] ela morre com 34 anos. (MUENSTER, 2019.)

Nesse caso, baseando-nos em Foucault (2007), que fala da produção da loucura como categoria social indesejante, podemos dizer que se evidencia nesse relato o silenciamento que impera em nossa sociedade sobre pessoas em sofrimento psíquico, o que faz com que suas histórias permaneçam escondidas; não sejam legadas às gerações futuras. Com a busca de Lucas, experimentamos uma pesquisa histórica a contrapelo, que procurou ouvir o silenciamento que se entremeou durante diferentes gerações da sua família e construir uma narrativa sobre a existência de sua trisavó, a partir dos rastros encontrados. As histórias de Hedwig e do Abrigo de Alienados Oscar Schneider, nesse sentido, compartilham um silenciamento em comum. Ambas as existências foram borradas, esfumaçadas, assim como a primeira palavra, aquela que antecedia Oscar Schneider na fachada do prédio.

Nas atuações individuais dos atores e atrizes, sentimentos e gestos eram vividos, inspirando-se nos corpos que viveram o isolamento manicomial (Figuras 4 e 5). Representou-se a angústia, o grito, o choro, o vagar incansável de um corpo aprisionado. Representaram-se também fragmentos de histórias orais, como o relato de uma antiga vizinha da instituição que narrou sobre a fuga dos "loucos" e o medo que isso causava na vizinhança, produzido pelo imaginário de periculosidade daqueles que ali eram confinados. 
"Memórias invisíveis": a produção de um documentário sobre o Abrigo Municipal de Alienados Oscar Schneider

Mariana Zabot Pasqualotto, Andrea Vieira Zanella

Figura 4 - Cena da atriz Andreia Malena

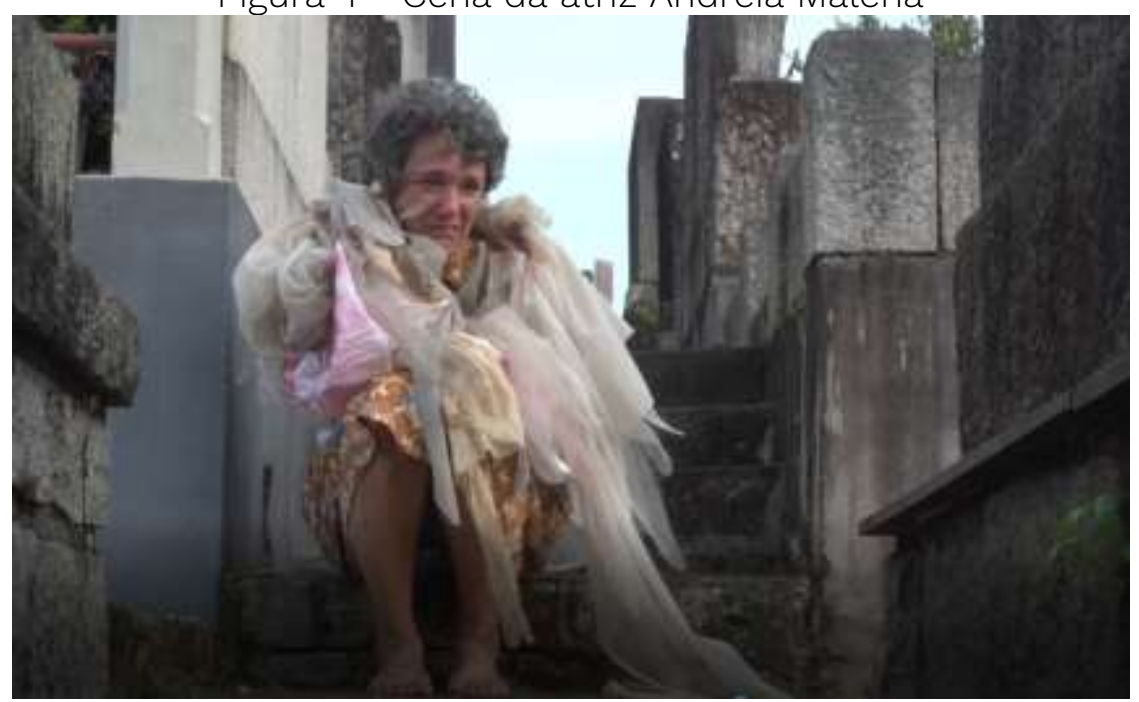

Fonte: Frame do documentário Memórias Invisíveis.

Figura 5 - Cena do ator Robson Benta

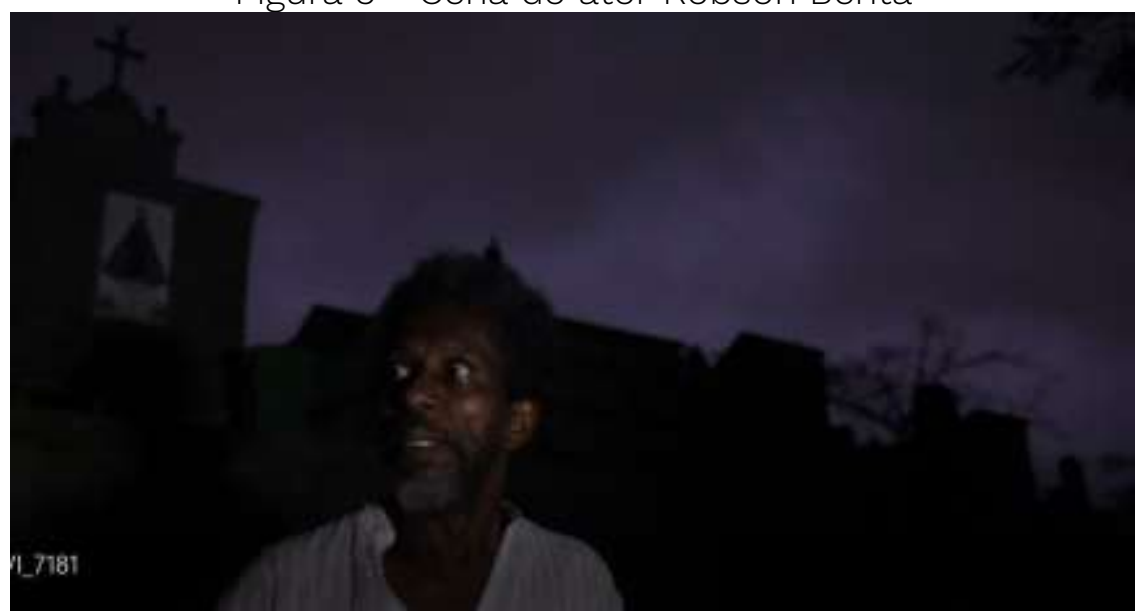

Fonte: Frame do documentário Memórias Invisíveis.

Esse relato veio de Nelsina Bachtold, indicada como testemunha da história do casarão por diferentes pessoas, pois havia dado entrevistas recentes à mídia local para contar suas histórias como vizinha do prédio que foi fundado para ser o Abrigo de Alienados. Nelsina viveu desde os oito anos de idade na casa vizinha, ou seja, desde o início dos anos 1940 e, por isso, possuía alguns resquícios de memórias sobre a instituição psiquiátrica, que funcionou até 1942. Nelsina relata:

Eu me lembro que meu pai plantava, tinha roça de aipim lá em cima, e ali quando era muito quente sempre tinha aqueles, aqueles que eram considerados loucos. E tinha um que chamava sempre "Calor, senhor! Calor, senhor!". Era muito triste ver aquilo. E o dono era um senhor alemão e eles tinham filhos, e eles de certo estavam muito bem de vida, tinham cavalos, e esses cavalos 
às vezes fugiam, eles estragavam nossas plantações. E a gente tinha um medo quando fugia um louco daquele. A gente fechava as portas e as janelas, e se escondia dentro de casa. [...] são lembranças bem longínquas. (BACHTOLD, 2019)

As lembranças de Nelsina são passagens que trazem alguns resquícios do cotidiano da instituição e da sua relação com a vizinhança, como no relato sobre as fugas e o medo diante disso, o que nos aproxima do imaginário social a respeito da presença do Abrigo de Alienados naquele território. Além disso, Nelsina traz a memória sobre um resquício oral da experiência da clausura, comunicado por uma das pessoas ali confinadas, ao seu pai: "Calor, senhor. Calor!". Talvez esse seja, até o momento, o mais próximo que nos encontramos da voz de quem viveu a experiência do confinamento no Abrigo de Alienados. Sobre a situação das pessoas internadas encontramos numa pesquisa na Biblioteca Nacional (no campo da hemeroteca) uma reportagem do Jornal "O Estado", do ano de 1936, uma descrição sobre a condição em que as pessoas confinadas eram encontradas:

Em recente reportagem, o nosso confrade "Jornal de Joinville" revela as tristes condições em que foi encontrar os alienados do "Hospício Oscar Schneider", daquela cidade. Os infelizes dementes acumulam-se em estreitas cellas e, nestas noites de frio, sem agasalho algum, dormem, encolhidos, a gemer, sobre rusticas estendidas no chão de cimento. Quando por mais não seja, ao menos dar a esse estabelecimento o auxílio mensal de vários contos, o governo do Estado acha-se no dever de syndicar por que motivo são tratados com semelhante deshumanidade os alienados do "Hospício Oscar Schneider. (CHOCANTE E CONSTRANGEDOR!, 1936, p. 6)

A reportagem denuncia a situação "desumana" do tratamento dado às pessoas no Abrigo de Alienados e reivindica esclarecimentos à instituição. Por meio da reportagem, temos pistas sobre a condição de vida dos internos, do sofrimento ali vivido, de como era o cotidiano daquele lugar, de como as pessoas passavam pelas condições do inverno ali, por exemplo.

\subsection{Sobrevivências}

Outro ponto a ser explorado é o tom espectral que a encenação dos atores acabou assumindo. Pensamos em um figurino com tecidos esvoaçantes, que 
"Memórias invisíveis": a produção de um documentário sobre o Abrigo Municipal de Alienados Oscar Schneider

Mariana Zabot Pasqualotto, Andrea Vieira Zanella

trouxesse a característica de vulto ao movimento dos atores e atrizes. Um dos atores, Robson Benta, levou no dia da gravação um longo lenço (figura 6) transparente que acabou se tornando um importante item para diferentes cenas da intervenção. O lenço parecia dar o tom espectral às cenas, e podemos pensar que ele representava as virtualidades, as reminiscências de tempos remotos que naquele lugar se fazem ouvir, ainda que sob a forma de sussurros.

Sendo conduzido pelos artistas, o lenço, em movimento, ora aparece e some das câmeras velozmente, ora permanece em interação com seus corpos por maior tempo. Pela sua característica transparente, o lenço pode nos remeter à invisibilidade, às coisas que são quase imperceptíveis ao nosso olhar, mas que, ao mesmo tempo, sobrevivem; são presença.

As cenas colocaram a interagir, portanto, no cenário de um cemitério, ausência e presença, representaram reminiscências, virtualidades, coisas que são e logo deixam de ser, ou seja, passaram a visibilizar rastros, a "[...] presença do passado desaparecido que faz sua irrupção em um presente evanescente" (GAGNEBIN, 2006, p. 44). Rastros que resistem com força e dificuldade à velocidade do "progresso" (BENJAMIN, 2012). Rastros que nos colocam diante da sobrevivência e da fragilidade da memória (GAGNEBIN, 2006).

Figura 6 - Ator Robson Benta e o lenço

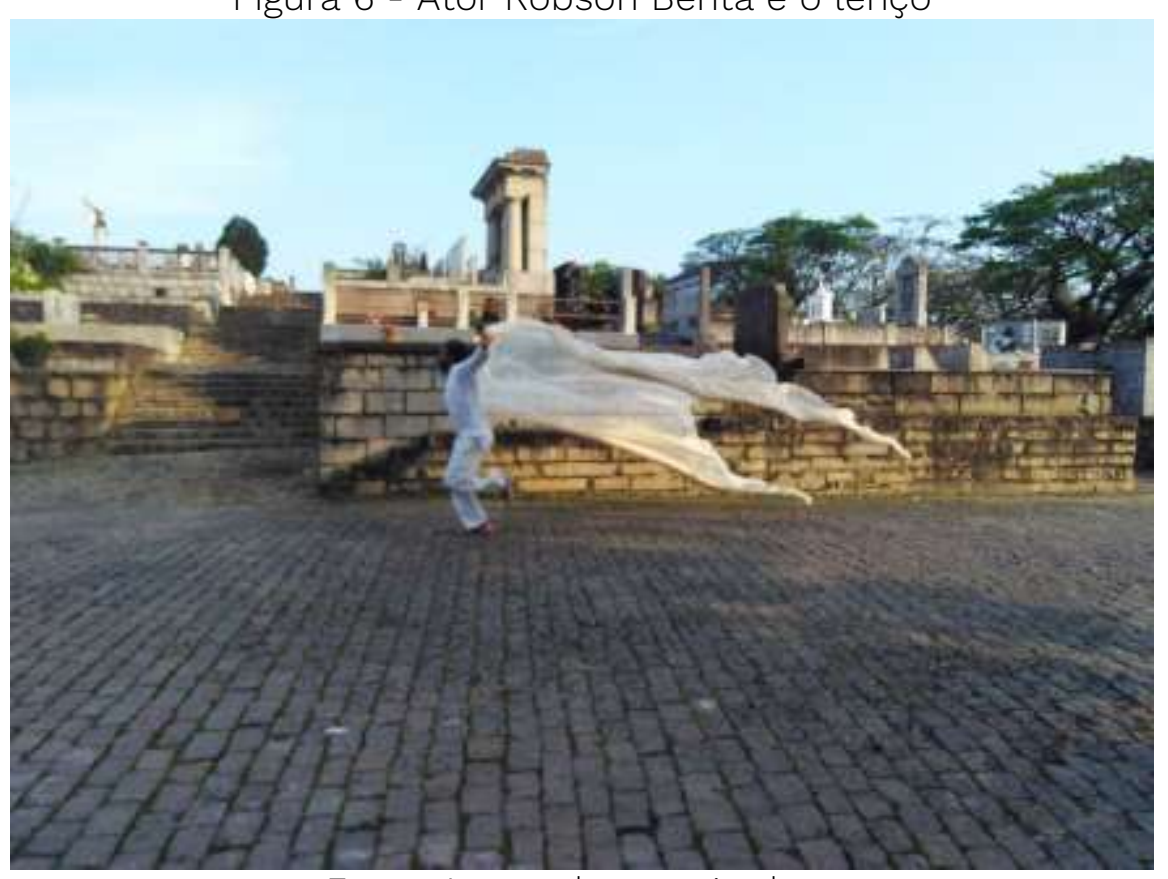

Fonte: Acervo da pesquisadora. 
"Memórias invisíveis": a produção de um documentário sobre o Abrigo Municipal de Alienados Oscar Schneider

Mariana Zabot Pasqualotto, Andrea Vieira Zanella

Assim como um lenço transparente que vagueia pelos ares, o sopro do passado também se faz sobrevivente, mesmo diante da ausência. Nesse sopro se conserva aquilo que ainda está sendo e aquilo que pode vir a ser. A transparência e leveza do lenço vagam quase imperceptivelmente pelos nossos olhares, assim como o faz o teor espectral do tempo histórico. Mas, quando em movimento, quando alguém ativamente busca lhe tocar, sentir sua textura e o fazer interagir no espaço, como nas cenas artísticas no cemitério, passamos a ser tocados pelo seu sopro.

Figura 7 - Atores interagindo com o lenço
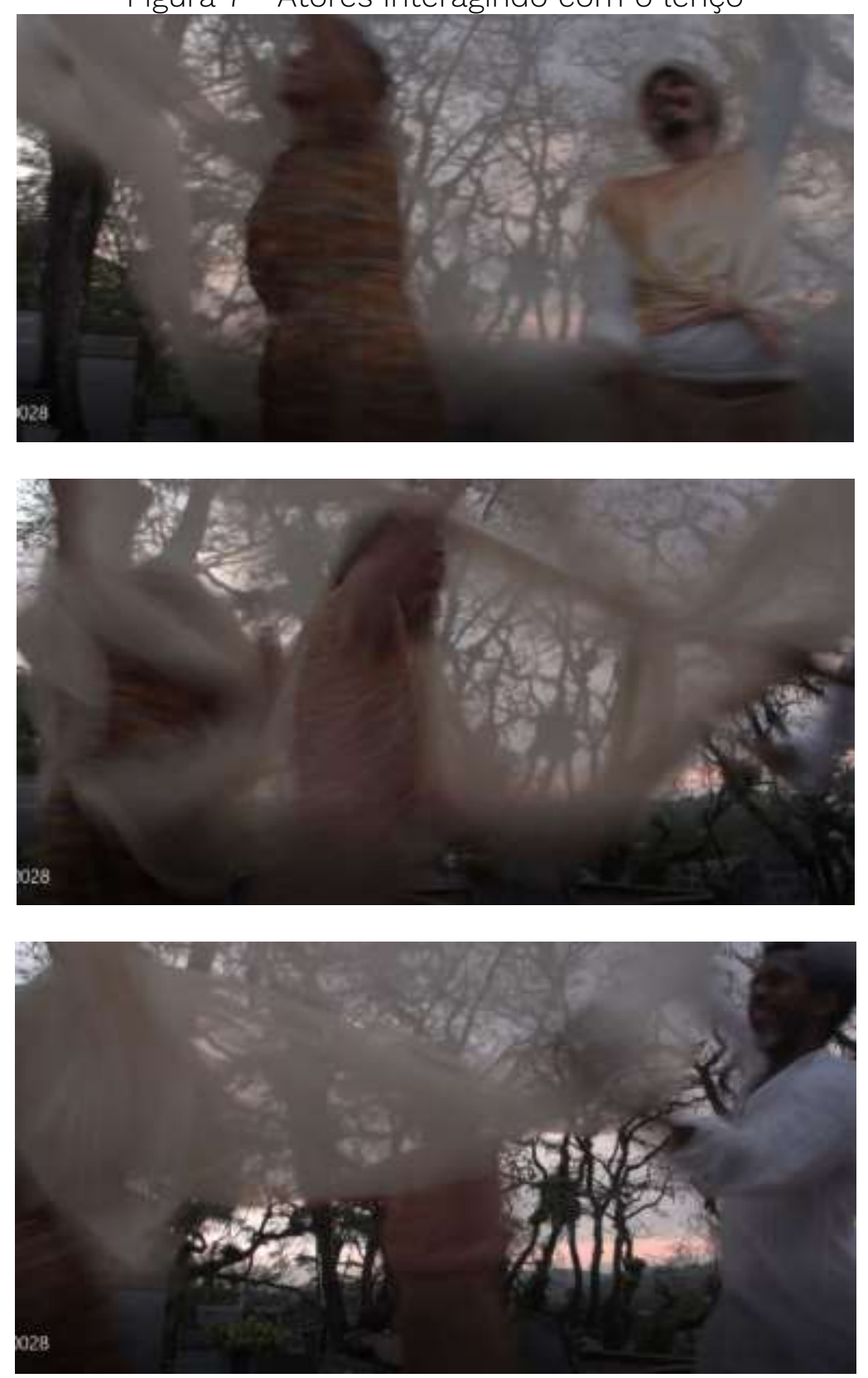

Fonte: Cenas do documentário Memórias Invisíveis. 
Com a cena artística e a figura do lenço como alegoria para pensar o sopro do passado (Figuras 6 e 7), é possível lembrar a ética benjaminiana da busca ativa pelo passado enterrado, a busca com a qual o pesquisador materialista histórico não pode se relacionar passivamente, deixando passar avisos do passado sem fazer irrupções no agora. Além disso, tais cenas visibilizam a espontaneidade dos corpos, a vivência daquele espaço de uma maneira outra que não a do confinamento. Eles aparecem correndo, brincando e interagindo com o lenço, representando outros possíveis às suas vidas, fazendo imaginar suas resistências, seus desejos contidos. A vida se esvai, e a performance nos faz ver o sopro que, liberto das amarras, transformado em miragem evanescente do que um dia foi, flutua por aquele lugar.

\section{Considerações finais}

A experiência desta pesquisa que tornou possível a realização do documentário "Memórias Invisíveis", apontou para a importância de atividades de difusão de memórias apagadas. Afinal, para tais memórias emergirem, dependese de ações que visem dar visibilidade para o que é supostamente insignificante. A produção do roteiro do documentário "Memórias Invisíveis" teve como objetivo promover uma recepção crítica e sensível aos/às expectadores/as a respeito das memórias sobre a história do tratamento à loucura na cidade, história sobre práticas de violência e assujeitamento de determinadas pessoas, que se encontram dentro de um escopo temático difícil de manter como narrativa citadina em circulação.

Pode-se pensar que a não demolição do prédio talvez garantisse maior vivacidade à narrativa sobre esse território infame da cidade. Mas, mesmo com sua presença, poderia persistir o esfumaçamento da sua memória, pois ela poderia ainda assim requerer agentes e ações para ser sentida no agora. Por isso, à impossibilidade da resistência física do prédio podemos lançar algumas perguntas: A que ela serviria? Transformar-se-ia em uma nova instituição de confinamento ou outro lugar infame da cidade? Seria habitada por uma função completamente diferente? Gostariam, suas primeiras testemunhas, aquelas que passaram pela experiência da clausura manicomial, que o prédio ainda estivesse 
"Memórias invisíveis": a produção de um documentário sobre o Abrigo Municipal de Alienados Oscar Schneider

Mariana Zabot Pasqualotto, Andrea Vieira Zanella

imponente na paisagem urbana? Essas perguntas nos fazem refletir sobre a implicação de ações patrimoniais - para além da questão da conservação ou não desse lugar - necessárias para a recordação e a elaboração de memórias de violências, pois tensionam possíveis repetições futuras. Ou seja, ações que não apenas conservem a "casca" dos patrimônios físicos, mas as relações e as experiências que nos espaços foram vivenciadas.

Nesse sentido, produções como o documentário, a performance e as projeções, o livreto e as exposições, assim como ações outras que podem ser construídas a partir de diferentes recursos a respeito das memórias do Abrigo de Alienados, servem para promover experiências contemporâneas em relação a esse passado, tensionar na esfera pública e cultural temas escondidos ou invisibilizados e, por último, como uma tentativa de elaborar uma experiência difícil, elaborar um luto de uma história que não havia recebido suas lápides. Lápides que agora talvez estejam mais visibilizadas à continuidade de escritas futuras.

\section{Referências}

ABREU, Regina. Colecionando museus como ruínas: percursos e experiências de memória no contexto de ações patrimoniais. Ilha Revista de Antropologia, Florianópolis, v. 14, n. 1, p. 17-35, jan./jun. 2012.

ASSMANN, Aleida. Espaços da recordação: formas e transformações da memória cultural. São Paulo: Unicamp, 2011.

BACHTOLD, Nelsina. Entrevista cedida à Mariana Zabot Pasqualotto, Joinville (SC), 24 set. 2019.

BAKHTIN, Mikhail. Problemas da poética de Dostoiévski. 5. ed., Rio de Janeiro: Forense Universitária, 2013.

BENJAMIN, Walter. Magia e técnica, arte e política: ensaios sobre literatura e história da cultura. 8. ed. rev. São Paulo: Brasiliense, 2012. 271p. (Obras escolhidas, v. 1). 
BORGES, Viviane T. Um "depósito de gente": as marcas do sofrimento e as transformações no antigo Hospital Colônia Sant'Ana e na assistência psiquiátrica em Santa Catarina, 1970-1996. História, Ciências, Saúde. Manguinhos, Rio de Janeiro, v. 20, p.1531-1549, n. 4, out./dez. 2013.

BUTLER, Judith. Vida precária. Contemporânea - Revista de Sociologia da UFSCar, São Carlos: Departamento e Programa de Pós-Graduação em Sociologia da UFSCar, n. 1, p. 13-33, 2011. Disponível em: http://www.contemporanea.ufscar.br/index.php/contemporanea/article/view/18. Acesso em: 23 out. 2020.

CHOCANTE E CONSTRANGEDOR! Jornal “O Estado”, Florianópolis, p.6, 25 jul. 1936. Disponível em: http://bndigital.bn.gov.br/hemeroteca-digital/. Acesso em: 19 mar. 2019.

COSTA, Luiz. A.; FONSECA, Tania M. G. A construção da civilidade: urbanismo, arquitetura e loucura na Porto Alegre de fins do século XIX e início do XX. Arquitextos (São Paulo. Online), São Paulo, v. 101, p. 7, 2008. Disponível em: https://vitruvius.com.br/revistas/read/arquitextos/09.101/105. Acesso em: 5 mar. 2019.

CUNHA, Dilney. Entrevista cedida à Mariana Zabot Pasqualotto, Joinville (SC), 30 ago. 2019.

D1. Entrevista cedida à Mariana Zabot Pasqualotto, Joinville (SC), 14 set. 2020.

D2. Entrevista cedida à Mariana Zabot Pasqualotto, Joinville (SC), 14 set. 2020.

DERRIDA, Jaques. Mal de arquivo: uma impressão freudiana. Tradução Claudia de Moraes Rego, Rio de Janeiro: Relume Dumará, 2001.

DIDI-HUBERMAN, Georges. Sobrevivência dos vaga-lumes. Belo Horizonte: UFMG, 2011.

DOCUMENTAR. In: DICIONÁRIO Priberam da Língua Portuguesa. Lisboa: Priberam Informática, 2021. Disponível em: https://dicionario.priberam.org/chave. Acesso em: 8 fev. 2021.

FERREIRA, Silvestre. Entrevista cedida à Mariana Zabot Pasqualotto, Joinville (SC), 20 ago. 2019.

FONSECA, Tania Mara Galli et al. Microfascismos em nós: práticas de exceção no contemporâneo. Psicol. clin., Rio de Janeiro , v. 20, n. 2, p. 3145, 2008. Disponível em: 
"Memórias invisíveis": a produção de um documentário sobre o Abrigo Municipal de Alienados Oscar Schneider

Mariana Zabot Pasqualotto, Andrea Vieira Zanella

http://www.scielo.br/scielo.php?script=sci_arttext\&pid=\$0103-

56652008000200003\&lng=en\&nrm=iso. Acesso em: 06 nov. 2020.

FONSECA, Tania M. G. Túmulo e palavra: o "After life" para prolongar um último toque com a ponta dos dedos. In: FONSECA, Tania M. G. (org.). Imagens do fora: um arquivo da loucura. Porto Alegre: Sulina, 2018. p. 257.

FONTOURA, Arselle. Aqui "Jaz" um Hospital. In: GUEDES, Sandra P. L de Camargo. Histórias de (i)migrantes: o cotidiano de uma cidade. Joinville: Editora Univille, 2005. p. 77-103.

FOUCAULT, Michael. História da loucura na idade clássica. São Paulo: Perspectiva, 2007.

GAGNEBIN, Jeanne Marie. Lembrar, escrever, esquecer. São Paulo: Ed. 34, 2006.

IDENIR. Entrevista cedida à Mariana Zabot Pasqualotto, Joinville (SC), 20 ago. 2019.

JOINVILLE. Relatório da Superintendência Municipal de 1922, redigido pelo superintendente Marinho de Souza Lobo. Joinville: [s.n.], 1922.

MARILU. Entrevista cedida à Mariana Zabot Pasqualotto, Joinville (SC), 20 ago. 2019.

MARISA. Entrevista cedida à Mariana Zabot Pasqualotto, Joinville (SC), 20 ago. 2019.

MUENSTER, Lucas. Entrevista cedida à Mariana Zabot Pasqualotto, Joinville (SC), 5 set. 2019.

PASQUALOTTO, Mariana Zabot; ZANELLA, Andréa Vieira; FONSECA, Tânia Galli. Se tudo ficasse quieto conseguiríamos escutar o rio?: uma intervenção urbana sobre memórias da cidade. Urdimento, Florianópolis, v. 2, n. 38, ago./set. 2020. Disponível em:

https://periodicos.udesc.br/index.php/urdimento/article/view/16675. Acesso em: 22 nov. 2020.

PASQUALOTTO, Mariana Zabot. Cidade, memória e infâmia: vestígios da clausura em Joinville/SC. 2016. 127 p. Dissertação (Mestrado em Psicologia) Universidade Federal de Santa Catarina, Centro de Filosofia e Ciências Humanas, Programa de Pós-Graduação em Psicologia, Florianópolis, 2016. Disponível em: http://www.bu.ufsc.br/teses/PPSI0683-D.pdf. Acesso em: 22 nov. 2020. 
"Memórias invisíveis": a produção de um documentário sobre o Abrigo Municipal de Alienados Oscar

RONI. Entrevista cedida à Mariana Zabot Pasqualotto, Joinville (SC), 20 ago. 2019.

SELMA. Entrevista cedida à Mariana Zabot Pasqualotto, Joinville (SC), 20 ago. 2019.

WADI, Yonissa M. Palácio para guardar doidos: uma história das lutas pela construção do hospital de alienados e da psiquiatria no Rio Grande do Sul. Porto Alegre: UFRGS, 2002.

ZANELLA, Andrea V. Sobre Arquivos, Testemunhos e Restos.... In: FONSECA, Tania M. Galli; FILHO, Carlos Antonio; RESENDE, Mario Ferreira (orgs.).

Testemunhos da infâmia: rumores do arquivo. Porto Alegre: Sulina, 2014. p. 119130.

ZANELLA, Andrea. Entre Galerias e Museus: diálogos metodológicos no encontro da Arte com a Ciência e a Vida. São Carlos: Pedro \& João Editores, 2017. 268p. 